\title{
Focal Segmental Glomerulosclerosis with Sjogren Syndrome: A Case Report
}

Mehmet SEZEN ${ }^{1}$, Abdülmecit YILDIZ1 ${ }^{1}$ Kamil DİLEK ${ }^{1}$, Mustafa GÜLLÜLÜ ${ }^{1}$, Mahmut YAVUZ ${ }^{1}$, Ayşegül ORUÇ¹, Mehmet Fethullah AYDIN ${ }^{1}$, Alparslan ERSOY ${ }^{1}$

${ }^{1}$ Bursa Uludağ University, Department of Internal Medicine, Division of Nephrology, Bursa, Turkey

\begin{abstract}
Cushing's disease (CD) constitutes most common cases of adrenocorticotropic hormone (ACTH) Sjögren's syndrome is a chronic lymphoproliferative disease. Sjögren's syndrome is rarely complicated by focal segmental glomerulosclerosis. Here, we presented a 39-year-old female patient with a history of Sjögren's syndrome for 5 years and diagnosed with focal segmental glomerulosclerosis.
\end{abstract}

Turk J Int Med 2021;3(Supplement 1):S107-S109 DOI: $\underline{10.46310 / \text { tjim. } 876204}$

Keywords: Sjogren syndrome, focal segmental glomerulosclerosis, nephrotic syndrome

\section{Introduction}

Primary Sjögren's syndrome (pSS) is a chronic, slow-progressing, autoimmune and lymphoproliferative disease. The syndrome's main symptoms are xerostomia and keratoconjunctivitis sicca as a result of chronic inflammatory infiltration of the salivary and lacrimal glands. The exocrinopathy can be encountered alone (pSS or in association with other autoimmune disorders, the three most common ones being rheumatoid arthritis, systemic lupus erythematosus, and progressive systemic sclerosis (secondary SS). ${ }^{1}$ Several systemic features have also been described; the presence of autoantibodies against the ubiquitously expressed ribonucleoprotein particles
Ro (SS-related antigen A - SSA) and La (SSB) underline the systemic nature of SS. The original explanatory concept for the pathogenesis of pSS proposed a specific, self-perpetuating, immunemediated loss of acinar and ductal cells as the principal cause of salivary gland hypofunction. ${ }^{2}$ SS-associated renal disease usually consists of tubulointerstitial nephritis ( $75 \%$ of patients) and glomerulopathy, such as membranous proliferative glomerulonephritis. ${ }^{3,4}$ Focal segmental glomerular sclerosis (FSGS) as a dominant pathological finding is found rarely in patients with pSS. Although rare, glomerulonephritis may accompany membranoproliferative glomerulonephritis, 
membranous nephropathy, and focal mesangioproliferative glomerulonephritis. In our case, FSGS, which is associated with pSS, was considered suitable for the presentation because of its rare occurrence.

\section{Case Report}

A39-year-old woman presented with bilateralleg edema. Urinary examination revealed increased urinary protein levels, and blood tests revealed hypoalbuminemia; thus, she was diagnosed with nephrotic syndrome. She reported a history of pSS diagnosed 5 years earlier. Physical examination of the bilateral lower extremities revealed pitting edema. Urinary examination revealed urinary protein levels of $4700 \mathrm{mg} /$ day, no hematuria. Blood tests revealed the following results: serum albumin $2.6 \mathrm{~g} / \mathrm{dL}$, blood urea nitrogen $20 \mathrm{mg} / \mathrm{dL}$, creatinine $0.6 \mathrm{mg} / \mathrm{dL}$, aspartate aminotransferase $22 \mathrm{U} / \mathrm{L}$, alanine aminotransferase $13 \mathrm{U} / \mathrm{L}$, and LDL cholesterol: $215 \mathrm{mg} / \mathrm{dL}$. Anti-SS-A and anti-SS-B antibody test results were positive. Tests for antinuclear antibodies showed a positive result. A kidney biopsy was performed, and the specimen included 23 glomeruli, with 3 showing segmental glomerulosclerosis, detected. There were six glomeruli in the immunofluorescence specimen. Immunofluorescence staining showed no glomerular deposition of immunoglobulin (IgG, $\operatorname{Ig} \mathrm{A}$, and $\operatorname{IgM}$ ), C3, or fibrinogen. Based on these findings, she was diagnosed with FSGS. The current patients did not show any electrolyte disturbances in the blood. The blood $\mathrm{pH}$ level of the patient did not show acidemia. Hepatitis markers were negative. Histopathological findings in kidney biopsy compatible with FSGS. Steroid (oral prednisolone at a dose of $15 \mathrm{mg}$ /day) and cyclosporine $(2 \times 100 \mathrm{mg} / \mathrm{d})$ therapies were initiated. Four weeks after initiation of steroid and cyclosporine therapy, the creatinine levels increased; hence, cyclosporin was discontinued. After 2 months of treatment initiation, urinary protein levels decreased to $303 \mathrm{mg} /$ day and creatinine $0.6 \mathrm{mg} / \mathrm{dL}$, and her leg edema disappeared. Steroid treatment was continued with $7.5 \mathrm{mg} /$ day oral prednisolone. Angiotensinconverting enzyme inhibitor (ramipril) was added to her regimen to decrease urinary protein levels.

\section{Discussion}

In the current case, the patient developed nephrotic syndrome secondary to FSGS. Typical renal complications associated with pSS are tubulointerstitial nephritis and renal tubular acidosis. Glomerular diseases manifested by nephroticsyndromeare infrequent in these patients. Although secondary FSGS could be attributed to several etiopathogenetic factors such as familial, viral, drug-induced, structural, and functional responses (nephron depletion and hemodynamic changes $)^{5}$, this patient showed no obvious findings that could have resulted in secondary FSGS. Therefore, we could not conclusively establish an association between pSS and FSGS. Goules et al. ${ }^{6}$ and Maripuri et al. ${ }^{7}$ reported only 5 cases of severe proteinuria or nephrotic interval out of 60 patients who underwent kidney biopsy in his studies. Unfortunately, Kurihara et $\mathrm{al}^{8}{ }^{8}$ reported that there had been no investigations or case reports that concern the prognosis and clinical response of the cases with FSGS and pSS. Therefore, to discuss the appropriate treatment or prognosis, further accumulation of similar cases with current patients is necessary. Because there are few cases of glomerular diseases coexisting with pSS, it is difficult to describe the best treatment options for each glomerular disease. ${ }^{8}$ Treatment for renal involvement primarily includes the administration of corticosteroid, and a few patients receive other immunosuppressants such as cyclosporine, cyclophosphamide, mycophenolate mofetil, and rituximab. Jasiek et al. ${ }^{9}$ and Ren et al. ${ }^{10}$ reported that 5 cases of 95 patients and 4 cases of 130 patients developed end-stage renal disease. In conclusion, limited data are available regarding renal involvement and prognosis in patients with pSS.

\section{Conflict of Interests}

Authors declare that there are none.

\section{Acknowledgment}

This study has been presented in $17^{\text {th }}$ Uludag Internal Medicine National Winter Congress, 
$6^{\text {th }}$ Bursa Family Medicine Association National Congress, $11^{\text {th }}$ Uludag Internal Medicine Nursing Congress, 5-7 March 2021, Bursa, Turkey.

\section{References}

1. Srinivasan S, Slomovic AR. Sjögren syndrome. Compr Ophthalmol Update. 2007 Jul-Aug;8(4):205-12.

2. Jonsson R, Vogelsang P, Volchenkov R, Espinosa A, Wahren-Herlenius M, Appel S. The complexity of Sjögren's syndrome: novel aspects on pathogenesis. Immunol Lett. 2011 Dec 30;141(1):1-9. doi: 10.1016/j. imlet.2011.06.007.

3. Yang HX, Wang J, Wen YB, Fei YY, Jiang MD, Zhou MY, Zhang W, Li H, Li XM, Zhang FC, Li XW, Zhang $X$, Chen LM. Renal involvement in primary Sjögren's syndrome: A retrospective study of 103 biopsy-proven cases from a single center in China. Int J Rheum Dis. 2018 Jan;21(1):223-9. doi: 10.1111/1756-185X.13182.

4. Kidder D, Rutherford E, Kipgen D, Fleming S, Geddes C, Stewart GA. Kidney biopsy findings in primary Sjögren syndrome. Nephrol Dial Transplant. 2015 Aug;30(8):1363-9. doi: 10.1093/ndt/gfv042.

5. D'Agati VD, Fogo AB, Bruijn JA, Jennette JC. Pathologic classification of focal segmental glomerulosclerosis: a working proposal. Am J Kidney Dis. 2004 Feb;43(2):368-82. doi: 10.1053/j. ajkd.2003.10.024.
6. Goules AV, Tatouli IP, Moutsopoulos HM, Tzioufas AG. Clinically significant renal involvement in primary Sjögren's syndrome: clinical presentation and outcome. Arthritis Rheum. 2013 Nov;65(11):2945-53. doi: 10.1002/art.38100.

7. Maripuri S, Grande JP, Osborn TG, Fervenza FC, Matteson EL, Donadio JV, Hogan MC. Renal involvement in primary Sjogren's syndrome: a clinicopathologic study. Clin J Am Soc Nephrol. 2009 Sep;4(9):1423-31. doi: 10.2215/CJN.00980209.

8. Kurihara S, Harada M, Ichikawa T, Ehara T, Kobayashi M. Nephrotic syndrome due to focal segmental glomerulosclerosis complicating sjögren's syndrome: A case report and literature review. Case Rep Rheumatol. 2019 Aug 15;2019:1749795. doi: 10.1155/2019/1749795.

9. Jasiek M, Karras A, Le Guern V, Krastinova E, Mesbah R, Faguer S, Jourde-Chiche N, Fauchais AL, Chiche L, Dernis E, Moulis G, Fraison JB, Lazaro E, Jullien P, Hachulla E, Le Quellec A, Rémy P, Hummel A, Costedoat-Chalumeau N, Ronco P, Vanhille P, Meas-Yedid V, Cordonnier C, Ferlicot S, Daniel L, Seror R, Mariette X, Thervet E, François H, Terrier B. A multicentre study of 95 biopsy-proven cases of renal disease in primary Sjögren's syndrome. Rheumatology (Oxford). 2017 Mar 1;56(3):362-70. doi: 10.1093/ rheumatology/kew376.

10. Ren H, Wang WM, Chen XN, Zhang W, Pan XX, Wang XL, Lin Y, Zhang S, Chen N. Renal involvement and followup of 130 patients with primary Sjögren's syndrome. J Rheumatol. $2008 \mathrm{Feb} ; 35(2): 278-84$. 